\title{
A Comprehensive floristic study of Van-Vihar National park Bhopal (M.P)
}

\author{
M.A. Zargar ${ }^{1 *}$, S. D. Singh ${ }^{2}$ \\ ${ }^{1}$ Dept. of Botany, Govt. Motilal Vigyan Mahavidyalaya, Bhopal, India \\ ${ }^{2}$ Dept. of Botany, Govt. Motilal Vigyan Mahavidyalaya, Bhopal, India \\ *Corresponding author: Zargarmuzafar.4u6@gmail.com,Ph. No. 7889983767
}

Available online at: www.isroset.org

Received: 01/Oct/2018, Accepted: 15/Oct/2018, Online: 30/Oct/2018

\begin{abstract}
Van vihar in the state capital Bhopal" is highly rich in floristic biodiversity of plants. Due to recent drastic changes after urbanization and industrialization have affect the Flora of Van vihar National park. In review of it after studied it is necessary to update and revise the flora of Van vihar National park. It has some hilly Tracks covered with luxuriant vegetation along with the forest area represented by deciduous spare forest. Taxonomical investigations were under taken to explore the floristic status of the ten dominant families. Conservation measures were also taken in account
\end{abstract}

Keywords: Floristic study, Dominant families, endangered taxa, conservation

\section{INTRODUCTION}

The awareness about and information on the floristic composition is inevitable for understanding the ecosystem of any given region. In fact, the inadequacy in taxonomic investigations has been a limiting factor in the study of tropical ecology (Hedberg, 1971). Most of the floristic in India were published during the last quarter of the nineteenth century. Several floristic accounts have been presented for different regions of state and includes those of Brandis (1874), Wood (1902), Hole (1904). While the composition of regional floristic has undergone a significant change under physical and biotic pressures over the years, the efforts to assess the current status of plant diversity have remained merge in the country . A number of species are endangered of survival and some have already been lost by the country. However recent urbanization, population exposition affect the flora of Van vihar National park. So, the main focused on comprehensive taxonomic biodiversity and conservation of view. It is necessary to explore existing floristic structure of Van Vihar update and revise the earlier data since several areas have either remained botanically unexplored or are underexplored

\section{RELATED WORK}

The related work includes those by Chaghtai and Ahmad (1977). Oommachan (1977), Khan and Chaghtai (1979), Khan (1980), Chaghtai and Garg (1981), Ahmad and Chaghtai(1982), Tiwari (1955), Narayanaswami and Rao (1969), Khan et al (1982), Khan and Chaghtai (1985) Khan et al (1989), S.S. Khan and Dolly Malhotra (2002)

\section{Methodology}

Field visits were undertaken at different seasions and collect the digital photographs in natural habit and plant specimen for observation, identification and data preparation in the laboratory during the study period. The plant specimen were identified with the help of different floras viz- Flora of India Hooker, (1872- 1897) flora of Bhopal, Oommachand (1977) Khan (1993). The herbarium was prepared for identification and nomenclature of species. The digital images were attached to the respective plant description. Various experts were also consulted for identification their systematic position and nomenclature of the species, genera and families and other literature

\section{RESUlts AND DiscuSSION}

The study identified 123 species belonging to 96 genera and 56 families out of these 94 species 69 genera belonging to 41 families of dicotyledonous, were as 29 species belonging to 27 genera and 15 families .The overall families to genera ratio is $1: 1.28$. Dicot to monocot family ratio is $2.73: 1$, where recording from Van Vihar National park. Some of the important conclusions emerging out of the investigations are presented.

1. Position of ten dominant species: - As per Hooker (187279), the Orchidaceae ranks first position among the Flowering plant families in India and fallowed by Fabaceae. The Latter is the most dominant family in Bhopal. The Ten dominant families of India and those of Bhopal are in table (1). In none of these studies the family Orchidaceae does not find any place among ten dominant families, were as it 
occupies the top most position in Hooker's Flora of British India. Fabaceae has unchanged position both in Hooker's, Oommachan's and Khans work. Poaceae ranks 111, Asteraceae finds $7^{\text {th }}$ position in British India Occupies $2^{\text {nd }}$ in flora of Bhopal (Oommachan, 1977 and Khans 1993) in present investigation Poaceae is at $1^{\text {th }}$ position were as in flora of British India, Oommachan, Khans studies presents at $3^{\text {rd }}$ position. The position of other families in comprasion with these studies shows that the family Ebenaceae does not take any place in these studies but it takes $10^{\text {th }}$ position in current investigation.

\section{Endangered species}

1. Asphodelus tenuifolius Cav.

2. Cochlospermum religiosum L.

3. Helicteres isora L.

4. Oroxylum indicum L.

5. Dioscorea bulbifera L.

\section{Exotic species}

1. Annona squamosa L.

2. Alternanthera pungens H.B.K

3. Gomphrena celosioides Mart.

4. Passiflora foetida L.

5. Lantana camara L.

\section{CONCLUSION AND FUture SCOPE}

The flora of the study were compared to early flora as Hookers (1872-97). Oommachan, (1977), Khans (1993) resulting the ten dominant families of the study area are Leguminosae, Poeaceae, Asteraceae, Amaranthaceae, Arecaceae, Rhamnacee, Malvaceae, Sapotaceae, Cyperaceae, Combretaceae. The revision of the flora of study area indicates the rich biodiversity region of medicinal and economically important plants which should be conserve for the feature generations by revision of the flora time to time

Table 1

\begin{tabular}{|c|c|c|c|}
\hline \multirow[t]{2}{*}{ Angiospermic } & \multicolumn{3}{|c|}{$\begin{array}{c}\text { Estimated representation of angiosperms in } \\
\text { Bhopal flora Number of estimated by }\end{array}$} \\
\hline & $\begin{array}{c}\text { Oommachan } \\
\text { (1977) }\end{array}$ & $\begin{array}{l}\text { S.S. khan } \\
\text { (2002) }\end{array}$ & Authors \\
\hline Families & \multirow[t]{2}{*}{121} & \multirow[t]{2}{*}{129} & \multirow[t]{2}{*}{41} \\
\hline Dicots & & & \\
\hline Monocots & 27 & 32 & 15 \\
\hline Total & 148 & 161 & 56 \\
\hline Genera & \multirow[t]{2}{*}{436} & \multirow[t]{2}{*}{503} & \multirow[t]{2}{*}{69} \\
\hline Dicots & & & \\
\hline Monocots & 108 & 132 & 27 \\
\hline Total & 544 & 635 & 96 \\
\hline Species & \multirow[t]{2}{*}{688} & \multirow[t]{2}{*}{818} & \multirow[t]{2}{*}{94} \\
\hline Dicots & & & \\
\hline Monmocots & 148 & 201 & 29 \\
\hline Total & 836 & 1019 & 123 \\
\hline
\end{tabular}

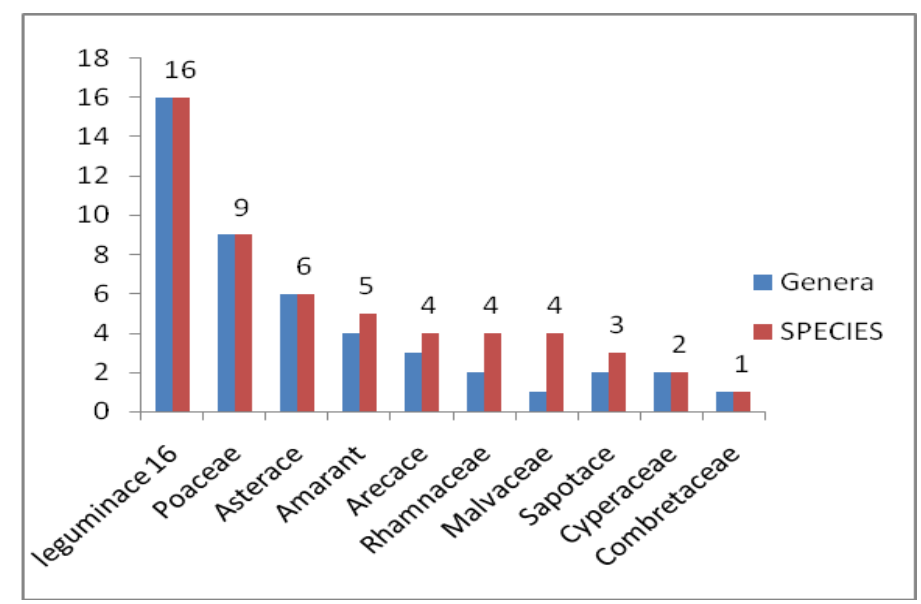

Figure .1

Table. 2

\begin{tabular}{|l|c|l|}
\hline Angiospermic & Position of ten dominant species \\
\hline India & \multicolumn{2}{|c|}{ Bhopal } \\
\hline $\begin{array}{l}\text { Hooker } \\
(1872-97)\end{array}$ & $\begin{array}{c}\text { Oommachan } \\
(1977)\end{array}$ & Authors \\
\hline Orchidaceae & Fabaceae & Leguminosae \\
\hline Fabaceae & Asteraceae & Poeaceae \\
\hline Poaceae & Poaceae & Asteraceae \\
\hline Rubiaceae & Acanthaceae & Amaranthaceae \\
\hline Euphorbiaceae & Euphorbiaceae & Arecaceae \\
\hline Acanthaceae & Scrophulariaceae & Rhamnaceae \\
\hline Asteraceae & Verbenaceae & Malvaceae \\
\hline Cyperaceae & Laminaceae & Sapotaceae \\
\hline Lamiaceae & Malvaceae & Cyperaceae \\
\hline Urticaceae & Convolvulaceae & Combretaceae \\
\hline
\end{tabular}

\section{ACKNOWLEDGMENT}

We are thankful to the authorities of our respective institution for providing the necessary facilities for accomplishing the present study which by no means is complete and final, and hence needs further work

\section{References}

[1] B.L Bentham, G. and J.D Hooke (1860). Genera plantarum,III,L. Reve and Co. London.

[2] B. G. and J.D Hooke (1860). Genera plantarum,III,L. Reve and Co. London.

[3] J. A and S.A. Chaghtai.( 1982). A study of flora of Bhopal with special reference to their medicinal value.Bull, Med, Ethnobot.Res. 3:144-52.

[4] R.S.Hole (1904). A contribution to the forest flora of Jubbulpore Division,Centre provinces, Indian for., 30: 499-514,566-92. 
[5] S.A. Chaghtai and A .Garg (1981).Evaluation and reassement of floristic composition of Euphorbiaceae of Bhopal with new records ,Jour.Sci.Res, 3(2): 141-145.

[6] S.A. Chaghtai, and J. Ahmad. (1977). An addition to our knowledge in flora of Bhopal, .M.P., India.J.Res.Ind.Med.Yoga Homoe, 12:102-104.

[7] S. S.Khan and D. Malhotra (2002).Angiospermic diversity in Bhopal: Reassessment with a particular refrance to endangered species and their conservation.In plant Genetic Diversity (Edts) s.pvij etal 77-99 pp. East-west press. New delhi India.

[8] S.S. Khan. (1996) .Endangered and Threatened Flora of Bbhopal .1.Trees. Indian J.Applied Pure Biol., 11:67-72.

[9] S.S Khan,. S.A. Chaghtai and M.Oommachan. (1984). Medicinal Plants of Rubiaceae of Bhopal: an ethnobotanical study.J.Sci.Res. 6, (1):37-39

(10] S.D.N. Tiwari (1955) . The Grasses of Madhya Pradesh. Indian for., 81: 107-115, 181-200.

[11] J. D, Hooker (1872-97). The Flora of British India.Vols.1-7.Reeve and Co., Ashford, Kent

[12] K.K Khanna. A. Kumar. R. D. Dixit and N.P Singh (2001). Supplement to the flora of Madhya Pradesh, Botanical survey of India, Calcutta.

[13] Linneans (1753). Species Plantarum in the genera of North America plants by Thomas N-uttal published by Hafner publishing co. New york- 1971.

[14] M. J Dallwitz (1980). A general system for coding taxonomic descriptions. Taxon, 29: 41-6.

[15] M. Oommachan, (1976). The Flora of Bhopal (Angiosperms). J.K. Jain Brothers, Bhopal

[16] O. Hedberg (1971) Tropical ecology and systematic Botany.Bull.Ecol.Res.Com., 13:122-23

[17] V.N. Swami and R.S. Rao (1969). A contribution to our knowledge of the vegetation and flora of Pachmarhi Plateau and the adjacent regions. J.India. Bot.Soc., 39:222-42

[18] Z.A. Lone. S.S Khan and F. Khan (2014) plant source for the healing of ophthalmic diseases of district Raisen (M.P), India. Indo American Journal of pharmaceutical Reserch 4(5): 2374-23786]

\section{AUTHORS PROFILE}

M. A. Zargar pursued M. Sc. in Botany and currently is puesuing Ph. D. in Botany at Barkatullah University Bhopal. Mr S. D. Singh currently working as Dean of Academic Faculty at Atalbihari Vijpayee Hindi University Kolar Bhopal M.P. The authors have published more than 10 papers in the reputed international journals. The research is based on the ecotaxonomy, particularly on the Van Vihar National Park Bhopal, M.P. 